\title{
How a Brazilian Public University Understands Sustainability: A Study Based on Sociological Discourse Analysis
}

\author{
José Florentino Vieira de Melo ${ }^{1}$, Ana Lúcia de Araújo Lima Coelho², Guilhardo Barros Moreira de Carvalho ${ }^{3}$ \& \\ Nicolle Sales da Costa ${ }^{4}$ \\ ${ }^{1}$ Master in Public Management and International Cooperation, Federal University of Paraíba, João Pessoa, \\ Brazil \\ ${ }^{2} \mathrm{PhD}$ in Business, Department of Business and Department of Public Management and International \\ Cooperation, Federal University of Paraíba, João Pessoa, Brazil \\ ${ }^{3}$ Graduate in Civil and Environmental Engineering, Federal University of Paraíba, João Pessoa, Brazil \\ ${ }^{4}$ Master in Public Policy and Higher Education Assessment, Federal University of Paraíba, João Pessoa, Brazil \\ Correspondence: José Florentino Vieira de Melo, Universidade Federal da Paraíba, Campus I, Pró-reitoria de \\ Administração, João Pessoa, Brasil, 58050-085. E-mail: jose.vieira.melo@icloud.com
}

Received: January 20, 2021 Accepted: February 24, 2021 Online Published: May 7, 2021

doi:10.5539/jms.v11n1p187 URL: https://doi.org/10.5539/jms.v11n1p187

\begin{abstract}
This paper aims to analyze the sustainability discourse manifested by a public institution dedicated to higher education located in the northeastern region of Brazil, the Federal University of Paraiba, during the time interval between the years 2009 and 2020. It used Sociological Discourse Analysis as a research method. It also used the documentation produced by the institution as a data source, in particular its Institutional Development Plans and Management Reports, as well as the media content produced and broadcast by its television channel and magazine. The research also used conversations held with employees linked to organizational management and observations recorded through photographs. Some questions were the basis for the data analysis: Who is the speaker; What is the position of the speaker; Which audiences did the speaker target; What did the speaker silence in the discourse; How did the speaker organize the speech; The research discovered discursive positions, narrative configurations, and semantic spaces that revealed an institution focused on its social function. It used teaching, research, and extension activities to be active in contact with society but placed its internal challenges in the background. It emerged that, despite understanding the importance of sustainability, internal actions to transform the organization into a laboratory for experimentation in this sense decreased due to the prioritization of combating recurrent socio-economic problems.
\end{abstract}

Keywords: discourse analysis, higher education, public management, sustainability, sustainable development, sustainable universities

\section{Introduction}

Language has one of its manifestations in the discourse: it assumes a prominent role in expressing a network of relations between ideology and power. The discourse displays the concept of the linguistics of meaning, one that goes beyond the words by entering the modality of the underlying persuasive exchange, an integral part of the word in context. Discourse is the object of appreciation of some research methods like the Discourse Analysis: this qualitative methodology seeks to unveil how what is said is produced, going beyond just seeking to understand or interpret, but seeking to highlight historical and ideological aspects (Barros, 2015).

Although it is a banality to hear about sustainability, scholars like Ferrer, Moreira, and Jesus (2019) warn of the lack of understanding of the general public about the scope of the expression. Some researchers tend to link the term to the environmental issue, forgetting its sphere in several other dimensions. Social actors develop their interpretation of sustainability and use it in their speeches to legitimize their actions as correct. Among the actors subject to investigation regarding their sustainability discourse, universities stand out as they face the challenge of reconciling the production of knowledge and the development of learning models more committed to the planet (Arroyo, 2017).

The research that culminated in this paper investigated the sustainability discourse expressed by a public 
organization, a federal institution of higher education located in the northeastern region of Brazil, the Federal University of Paraiba (UFPB). The reference to manifest refers to the act of revealing ideas or thoughts. In this sense, the manifestation of discourse happens over time, changing and reflecting the political, social, and ideological contexts that shaped it.

UFPB started its activities in 1955. In 2020, it presented a structure divided into four campuses, the main one being in Paraiba's largest city, João Pessoa. The campuses encompass sixteen centers, 128 undergraduate courses, 110 graduate courses, in addition to various research and extension activities (UFPB, 2019c). Other investigations revealed the administrative complexity of organizations of this size (Aligleri, Aligleri \& Kruglianskas, 2009; Pantaleao, 2017), which face daily challenges related to the most diverse factors such as infrastructure, maintenance, waste disposal, urban mobility.

This research used the Sociological Discourse Analysis methodology to analyze the following question: how is the sustainability discourse manifested in a federal higher education institution? The study had as sources of investigation the last two Institutional Development Plans (IDPs) presented by UFPB, which were in force from 2009 to 2013 and 2014 to 2018 (UFPB, 2010, 2014), as well as the current one in the period of the research, whose validity extended from the years 2019 to 2023 (UFPB, 2019a). This way, the research interval goes from 2009 to 2020 .

In addition to the IDPs, we searched the Management Reports for the demarcated period (UFPB, 2019b); the communication produced by the institution, aimed at the internal public and society; photographs obtained during on-site observations; informal conversations with employees, in particular with those who deal directly with the research topic. We sought to understand if what was said formally and informally was put into practice or not. We also wanted to understand whether ideological, social, political, historical, or economic factors influenced both the manifested discourse and its materialization in the form of actions.

This paper has four sections in addition to this introduction. Section 2 presents the theoretical basis of the investigation. Section 3 points out the methodological procedures used in the study. Section 4 identifies the results of this work, obtained with the Sociological Discourse Analysis of the corpus: we interpose these results to detect congruences and divergences between the discourse and the practice of sustainability at the Federal University of Paraiba, as well as contexts and ideologies that acted in their formulations. In Section 5, we provide an overview of the research: we expose its weaknesses and make recommendations to researchers.

\section{Theoretical Frameworks}

This Section presents the theoretical artifact gathered as a support for carrying out the analysis of the sustainability discourse manifested by the university. Orlandi (2015) argues that the corpus assembled requires the mobilization of concepts relevant to the proposed research question. These concepts form the basis for the researcher to deconstruct and analyze the discourses, exposing what is not clear in what is said.

\subsection{Sustainability: Concepts, Debates, Dimensions}

The 20th century was a scene of deep mutations in the relationship between humans and nature, marked by discussions about the economic growth model in force, based on the intensive use of natural resources and patterns of accelerated consumption in industrialized nations as a result of technological development (Nascimento, 2012). In the 1980s, the United Nations formed the World Commission on Environment and Development, which published the report Our Common Future, whose mission was to propose a global agenda for changes in various aspects of the economy, society, and the environment. The document sought to link the concepts of technology, economics, society, and politics, suggesting an ethical stance based on the precept of responsibility between generations and the systemic view of environmental issues focusing on the historical origins of socioeconomic and ecological problems. Nascimento (2012) observes that the report had as strengths and weaknesses, at the same time, its vague formula that left open both the definition of current and future needs.

In the 1990s, Elkington appropriated terms specific to organizational practices when launching his definition of sustainability (Laurell, Karlsonn, Lindgren, Andersson \& Svensson, 2019). He observed this concept as a principle that ensures that the actions taken in the present do not limit the range of economic, social, and environmental options available in the future. The author used a measurable model, known as the Triple Bottom Line (TBL), based on three guiding pillars of business actions: economic, social, and environmental. Elkington made it clear that there is an interdependence between the supports, which constantly flow due to political, social, economic, or natural pressures. In this context, real sustainability happens when there are coexistence and cooperation between the three of them.

Hammer and Pivo (2016) indicate some points to promote theory and practice in organizations, public or private: 
training and certification as a way to develop skills both in leaders as well as others involved in the institutions' daily lives, thus encouraging their systemic use; evaluation of the impacts of the Triple Bottom Line approach on the organization's results, both ex-ante, through the analysis of risks and scenarios, and ex-post, using reports and metrics; encouraging research that relates the systematic use of TBL to organizational results.

In 2000 the Millennium Summit took place, under the sponsorship of the United Nations. The member countries signed the so-called Millennium Declaration: this document defined the fight against hunger as the central global challenge, recognizing the existing inequality between industrialized, developing nations and economies in transition (Roma, 2019). The Declaration originated, in 2001, the Millennium Development Goals: these should be achieved by the signatory countries by the year 2015 and covered actions to combat poverty, health policies, sanitation, education, housing, promotion of gender equality, sustainable development. Carvalho and Barcellos (2015) note that the goals had the intention to act as a stimulus to help from rich countries to the poor and to a higher commitment by both groups to increase human development rates. However, they note an excessive focus on goals that did not take regional inequalities into account and paid little attention to differences between social groups.

In 2015, the UN Sustainable Development Summit launched a new agenda, known as the Sustainable Development Goals (SDGs). Carvalho and Barcellos (2015) interpret them as more ambitious than the Millennium Development Goals as sixteen are themed and structured in the dimensions of the Triple Bottom Line. Furthermore, one addresses the need to create partnerships for the implementation of others, ranging from governments to civil society and multinational organizations. According to the authors, the process of elaborating the SDGs was more democratic because it allowed space for discussion and social participation, although the result was too long.

Carvalho (2019) identifies two visions for sustainability and sustainable development definitions. One understands that sustainable development is the way to obtain sustainability, the long-term objective. The other understand sustainability as the balance of the Triple Bottom Line and sustainable development as the goal, whereas sustainability is the process to achieve it. This research followed the path that sees sustainability as an objective and sustainable development as an intermediary to complete the first. This way, sustainability is understood as a broader concept, which does not place economic growth as a cornerstone of debates.

\subsection{Universities and Their Links with Sustainability}

In 2002, the United Nations General Assembly proclaimed the period between 2005 and 2014 as the International Decade of Education for Sustainable Development (IDESD). They emphasized the challenge of encouraging changes in attitude and behavior in populations, "since man's intellectual, moral and cultural capacities impose responsibilities on other living beings and nature as a whole" (UNESCO, 2017). Reflecting on the IDESD context, Bastos (2016) points out public policy initiatives aimed at environmental education implemented in Brazil since the 1980s, namely: inclusion of it as a right of all and duty of the State in the Federal Constitution; creation of environmental education centers by the Brazilian Institute of the Environment and Renewable Natural Resources and the Brazilian Ministry of Education in 1992; institution of the National Environmental Education Program in 1994; approval of the National Environmental Education Policy in 1999.

In the 2000s, the Federal Universities Restructuring and Expansion Plans (REUNI), created and expanded by Brazilian governments linked to left-wing ideologies, represented an opportunity for public universities to meet the needs and ideas propagated by the declarations and events that occurred over the years. Paula (2018) analyzes that public universities have prioritized, in their plans, university expansion linked to the size as a way of giving access to higher education to historically marginalized social groups. In a favorable budgetary scenario, federal universities grew, leaving environmental aspects in the background. The social duty was the focus of concerns: from the Triple Bottom Line, plans linked to REUNI turned their lenses to the social field.

Aleixo, Leal, and Azeiteiro (2018) recognize that universities play an extensive role in promoting sustainability. Stakeholders expect that these organizations act focusing on sustainability. It may happen by overcoming challenges such as ambiguity and complexity surrounding the notion of sustainability, a factor that has contributed to prioritizing, in REUNI's plans, the social focus. Other challenges are the lack of funds and financing directed specifically at implementing sustainable behavior; resistance by stakeholders to accept changes in behavior and practices; the lack of commitment, interest, and involvement of managers; the lack of training and specialization in sustainability.

Adams (2013) understands that some factors are decisive to implant a culture concentrate on sustainability in universities: proactive leadership; clear and consistent communication; the inclusion of sustainability in the organizational strategy; multidisciplinary in courses and research; student and employee engagement; and other 
initiatives that can develop sustainable practices. Arroyo (2017) summarizes four areas that should be considered by managers when formatting a university committed to sustainability: curriculum, with the integration of topics related to sustainability in courses' pedagogical plans, and the creation of elective courses focused on the theme; research, with the inclusion of sustainability in ongoing projects, with support for interdisciplinarity; dissemination, with community involvement and the promotion of public debates on the topic; and operations, with the implementation of green practices such as recycling, energy consumption, water reuse, transportation sharing.

In 2018, the Federal University of Paraiba approved its environmental policy based on sustainable development; ecological balance; broad community participation; responsibility; internalization of natural issues in all activities (administrative, teaching, research, or extension); adequate and rational management of used resources; governance, control, and risk management (UFPB, 2018). In this document, the University demonstrated some commitment to actions to avoid pollution, conserve and restore the environment. UFPB's Environmental Management Commission developed this policy, which has as one of its objectives "to articulate, guide, prioritize, regulate, monitor, register and evaluate institutional management and environmental education programs" (UFPB, 2018). The Federal University of Paraiba history shows signs that may help the reveal of silences in the sustainability discourses expressed by the institution.

\section{Research Methodology}

This research is a qualitative work for having an exploratory character, inductive focus, and priority to the social aspects that contributed to the shape of the reality that we seek to understand. It is a case study since it suggests an in-depth examination of a subject through its speeches and the immersion in its daily life. Data exploration took place through Sociological Discourse Analysis, an examination method of Spanish tradition (Alonso, 1998; Conde, 2009; Ibanez, 1985; Orti, 1986).

The Sociological Discourse Analysis enables to capture the unsaid amid speeches, to reveal the ideologies that shape them, and it is up to the researcher to select the relevant contexts for his investigation. In this sense, we researched documents produced by UFPB: in particular, the last two Institutional Development Plans, which were in force between 2009 and 2018 (UFPB, 2010, 2014), as well as the Plan in vogue at the time of the research (UFPB, 2019a), and the Management Reports corresponding to this period until the year 2019, the last one published while the study took place (UFPB, 2019a).

Other sources were the material produced and disseminated via a television channel and editions of UFPB.BR Magazines, quarterly printed booklets that serve to propagate actions carried out by the organization. Immersion in the organization's daily life to witness practices focused on sustainability that happen or not; informal conversations with employees, some of them linked to work-related to sustainability issues, others not. Table 1 shows the sources chosen as well as the reasons for their choices.

Table 1. Justifications for defining the corpus

\begin{tabular}{ll}
\hline DATA SOURCE & PERCEPTION OF RELEVANCE TO THE CORPUS \\
\hline $\begin{array}{l}\text { Institutional Development Plans } \\
\text { (IDPs) }\end{array}$ & $\begin{array}{l}\text { The IDP is the guiding instrument for the institution's management practices, articulating the other } \\
\text { institutional projects in the sense of building a democratic management model that supports the } \\
\text { consolidation of its goals } \\
\text { The MR is an integral part of the rendering of accounts to the Federal Government, legally guided by } \\
\text { rules: it contains data guidelines on the operation, planning, resources, works, not to mention } \\
\text { fundamental areas such as teaching, research, and extension }\end{array}$ \\
& TV UFPB intends to meet the aspirations of society for public television, to offer an informative, \\
& educational, cultural, artistic, scientific, and citizenship-forming program \\
TV UFPB & $\begin{array}{l}\text { The editions seek to expose the importance of the environment for Paraiba's society, and consequently } \\
\text { for the country, through the diverse actions of the institution }\end{array}$ \\
UFPB Magazine & $\begin{array}{l}\text { Here, it is no longer a matter of separating, trichotomizing text-speech-image. It must be considered } \\
\text { that the visual way of life refers to a particular form of construction and expression of meaning, a } \\
\text { form that we no longer have to go back (Godoi \& Uchoa, 2019) } \\
\text { They intend to obtain information of a pragmatic type in the search for how the discursive subjects act } \\
\text { and reconstruct the system of social representations and individual practices regarding the } \\
\text { Informal conversations with }\end{array}$ \\
employees & sustainability discourse (Coelho, 2012) \\
\hline
\end{tabular}

Source: elaborated by the authors, 2021 . 
For Sociological Discourse Analysis, the corpus, even in different formats, must be seen as a single entity (Coelho, Coelho \& Godoi, .2013). When collecting and analyzing separate entities, the analyst must focus on the totality of the material to understand if there are continuities or ruptures between different discourses or between discourse and practice (Godoi \& Uchoa, 2019). Table 2 presents the specific objectives of the research, the data sources selected concerning each goal, and the expected results with the analysis of each one.

Table 2. Sources for data collection and expected results

\begin{tabular}{|c|c|c|}
\hline SPECIFIC OBJECTIVE & DATA SOURCES & EXPECTED RESULTS \\
\hline $\begin{array}{l}\text { Identify the organization's formal discourse } \\
\text { regarding the sustainability within the defined } \\
\text { period }\end{array}$ & $\begin{array}{l}\text { IDPs; management reports; media } \\
\text { content produced by UFPB }\end{array}$ & $\begin{array}{l}\text { Verification of what is said formally by the } \\
\text { university about its relationship with } \\
\text { sustainability }\end{array}$ \\
\hline $\begin{array}{l}\text { Identify the organization's informal discourse by } \\
\text { observing sustainable practices performed and } \\
\text { the statements of its employees }\end{array}$ & $\begin{array}{l}\text { Observations on campuses; informal } \\
\text { conversations with employees }\end{array}$ & $\begin{array}{l}\text { Presentation of internal practices related to } \\
\text { sustainability and aimed at achieving the } \\
\text { objectives of its environmental policy }\end{array}$ \\
\hline $\begin{array}{l}\text { Contrast congruences and divergences between } \\
\text { discourse and sustainability practice at UFPB }\end{array}$ & $\begin{array}{l}\text { Analysis and crossing of the data } \\
\text { obtained in the previous steps in the } \\
\text { light of Sociological Discourse Analysis }\end{array}$ & $\begin{array}{l}\text { Identification of contexts and ideologies that } \\
\text { guided the organizational discourse and whether } \\
\text { the practice corresponds to the discourses }\end{array}$ \\
\hline
\end{tabular}

Source: elaborated by the authors, 2021.

Once the Federal University of Paraiba formalized its environmental policy in 2018, we used it as a benchmark for the analysis. Even having the policy as a model for the investigations, because of its formal character, in certain moments, it was necessary to extrapolate it. We exposed links between the discourse and the Triple Bottom Line. We also detailed some connections with global plans like the Sustainable Development Goals.

\subsection{Data Analysis Procedures}

Sociological Discourse Analysis is applicable in investigations based on interviews, triangular groups, and corpus analysis based on writing, news, or even photographs (Coelho, 2012). The methodological and technical aspects of the inquiry are the foundation of the investigation and determine the construction of the discourse system (Alonso, Rodriguez \& Rojo, 2016).

The procedural steps are flexible and mix during the work in a continuous coming and going between the theoretical artifact and the collected data, but serve as a guide to practice, preventing the researcher from getting lost in the corpus or confusing creativity with methodological anarchy (Alonso et al., 2016). Thus, we divided the data analysis processes into three stages: initial works, interpretation, and analysis. All the stages have taken place concurrently with the others at certain times, according to the need.

In the initial works, we separated the corpus into two groups. The first dealt with the formal manifestations of the discourse, composed of material produced in an official character by the researched institution - documentation and media material published by the press that is part of the organizational structure. The second investigated the informal manifestations of the discourse - here, the content obtained more spontaneously was grouped, through the employees' speeches collected in conversations and images obtained from non-participant observations carried out in the physical space of the university. From this division onwards, we made general readings and notes in texts and images according to each type of source, respecting their chronological order. This separation of the discursive sources occurred to promote the perception of context's influences in the discourses and its relevance in different media (Coelho, 2012).

As the first procedures for the data interpretation, hypotheses were made, called pre-analytical conjectures (Godoi, Coelho \& Serrano, 2014). It was the moment when the first intuitions appeared. They attempted to formalize the more general apprehension of texts and images. They could or could not be correct by the end of the research according to their coherence and consistency with the analyzed material.

We identified the discursive styles within each source from an analysis "of the most expressive, idiosyncratic, singular, enunciative forms, of expressive turns, narrative styles and types of approach / discursive construction of a social phenomenon" (Coelho, 2012, p. 201). This identification pointed to ideologies that shaped the statements, purposeful silences that camouflaged meanings for what was said, providing subsidies for the analysis procedures.

Interpretation works progressed globally through the corpus, happening in a partially simultaneous way to the previous stages. This grade sought to contrast the two types of manifestations studied - formal and informal-to 
reveal approximations and distances between discourse and perceived reality. In addition, we deepened the capture of the destination of the manifested speech and the actions or policies interpreted by the institution as priorities.

The discursive positions attempted to apprehend the subjects' perspectives on the theme. They reveal who spoke and the speech position. They also identify the polarization or not of dominant spots, social representation, and the generalization of discourse (Coelho et al., 2013): individual or group positions began to emerge clear, with the social place of everyone.

The narrative configurations tried to answer the questions: What are the subjects addressed in the speeches? What ideologies shaped the discourse? We capture dimensions, axes, or vectors that point to a common direction for the corpus, tensions, conflicts, and differences in positions and opinions expressed by the subjects. The objective of this stage was to identify the leading axis of the message indicated by the discourse.

The analysis of semantic spaces involved simple elements, such as the principal verbal and symbolic expressions that configured the field of meanings of each area and the discursive axes that linked one or another semantic attraction (Coelho, 2012). Here, we found responses to the demands: How is the speech organized? What is not said but perceived in the discourses? We analyzed the use of language, the connection or dissociation of speech in different ways of approaching the research object.

\subsection{Pre-Analytical Conjectures}

The first readings carried out, when this research started, made it possible to awaken to the investigation that Conde (2009) calls sociological imagination, an action that admits to thinking conjectures capable of demarcating the lines of work and that is changing as new ideas go arising from the data analysis. For Coelho (2012), the hypotheses are anticipations guided by the possibilities of answers to the questions proposed in the research, derived from the researcher's theory, observations, or experience, and are also called pre-analytical conjectures. The researcher seeks to find ways to weave together a set of elements that, at first, might be different in origin or content.

The central conjecture assumes that the Federal University of Paraiba's concern and involvement with sustainability has gradually increased over the years. This theory guided the perception we had about discursive sources and supported a continuous dialogue between the imagined and the observed reality. We considered this for the interpretation of the discourse found in the selected sources. It follows the inference that the institution's sustainability discourse has evolved as more attention and more interventions have taken place. The more recent the period, the more prominent UFPB's level of influence on issues related to sustainability, and therefore the lower the negative impact generated on the nature of its surroundings and social issues.

The research corpus, in particular Institutional Development Plans and Management Reports, when analyzed by the Sociological Discourse Analysis, must demonstrate greater attention to the subject year after year, thus validating the conjecture raised here. We presume that, while the discourse evolved, the same occurred with interventions practiced for socio-environmental sustainability. In this sense, the university seeks to reduce its aggression towards nature and the negative impact of its actions, keeping its discourse and practices aligned.

\section{Results' Introduction, Analysis, and Discussion}

After data collection, there was a confrontation between the formal and informal manifestations of the UFPB sustainability discourse to contrast congruences and divergences between expression and practice. Therefore, we attempted to understand, from the perspective of Sociological Discourse Analysis, the discursive positions, narrative configurations, and semantic spaces that delimit points and manifestations of the sustainability discourse of the federal institution of higher education studied here.

\subsection{Discursive Positions}

The discursive positions are associated with a kind of general orientation to scrutiny different forms of manifestation of the sustainability discourse. The investigation of the distinct materials collected, formal and informal, allowed to establish comparisons that exposed approximations and distances between points of view and rhetoric. These comparisons were possible when asking the material what kind of logic appears in the UFPB discourse through each source. The questioning led to a graph (Figure 1) where we positioned the organization's relationship with the sustainability discourse over time. 


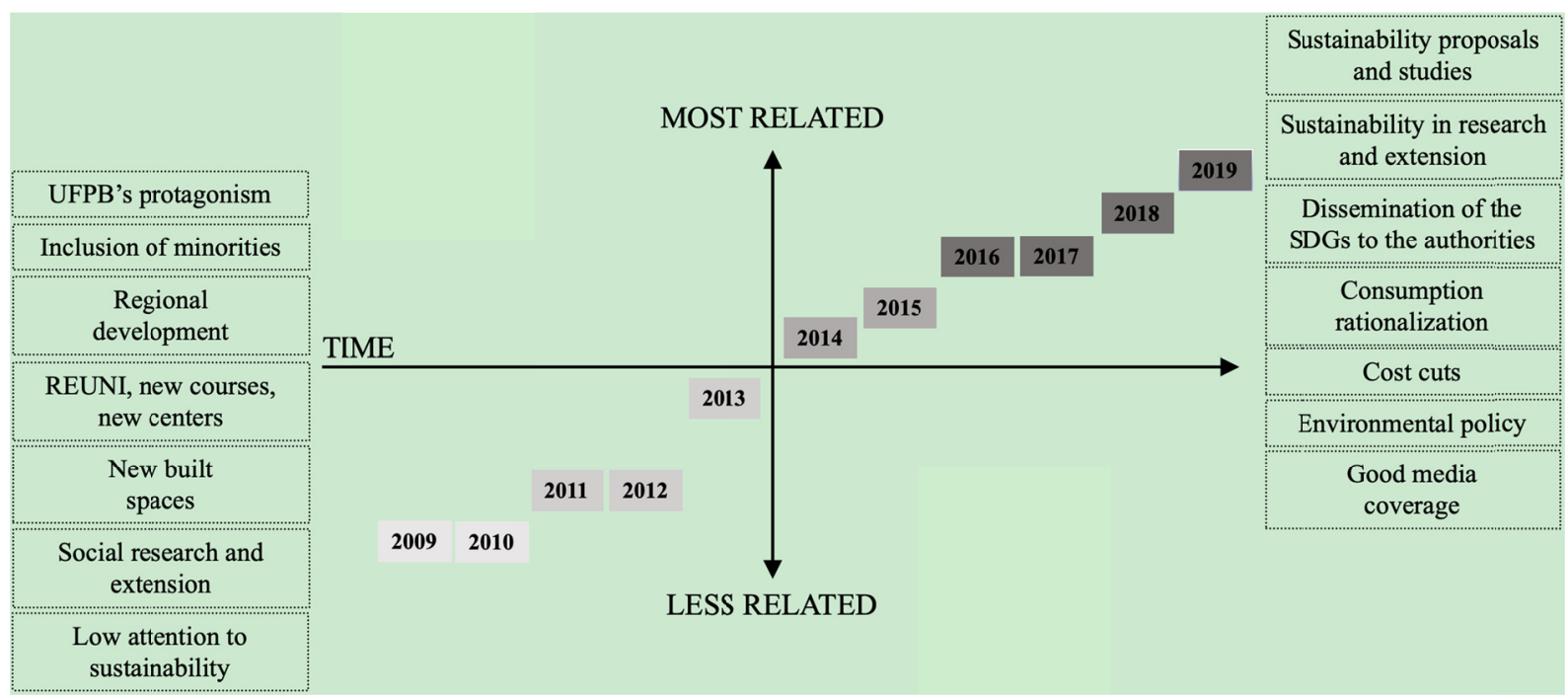

Figure 1. Relationship between discourse and sustainability over time

Source: elaborated by the authors, 2021.

The graph corroborates the conjecture of higher attention paid to the discussion of sustainability over time, thus expressing the image of a university that has experienced a maturation related to the theme. We see it in the rhetoric of the management, as well as in their media dissemination. It deserves attention, however, the fact that this maturation is not reflected broadly throughout the institution. According to the data collected, there are nuclei that experience sustainability in teaching, research, extension, or through responsibility for the practical application of the theme in university management. Figure 2 shows the discursive positioning over time of each of the sources researched.

The study of Institutional Development Plans led to the impression that the attention paid to sustainability issues gradually increased. In the first Plan analyzed, social responsibility was the only dimension contemplated, while the last one addressed several themes related to sustainability. Considering the four areas relevant to the formation of a sustainable university defended by Arroyo (2017), the Institutional Development Plans focused their attention on the field of operations, with timid mention of curriculum, research, and dissemination.

Likewise, the examination of eleven Management Reports - published between 2009 and 2019-led to the impression that the university was, over time, gradually giving greater attention to issues related to sustainability. In the first reports, nothing was said about it, while, in 2019, there was an attempt to cover all the Triple Bottom Line. Notably, the discourse favored operations and research, keeping on a secondary position contact with society and curricular changes to integrate sustainability in course programs.

The university's media outlets proved to be a prolific means of disseminating ideologies dear to managers. The campaigns published on TV UFPB fit within university environmental policy. However, the speech did not express systemic actions aimed at changing habits in the community but referred to needs generated by momentary contingencies. We noticed this more clearly when looking at articles that dealt with campaigns to reduce paper use and save electricity: both spoke of budget restrictions and brought little reflection on their reach or the implementation of changes that collaborate for higher long-term financial savings.

Some UFPB.BR Magazine reports referred to issues also addressed by TV UFPB, such as dissemination of actions aimed at accessibility. The attention given to these issues reveals an institution's need to present itself as inclusive and plural. The political discourse analyzed in the Institutional Development Plans or Management Reports was repeated in the editions of the magazine and on TV. In principle, the university expanded its activities with the opening of campuses and courses. After 2016, efforts focused on maintenance and the search for containment alternatives that avoid cuts in activities with consequent losses to the population. Different managements used the same discourse, which evaluated the university as the structural organ for social assistance and scientific development. This observation identifies an ideologically homogeneous UFPB even with disagreements typical of an environment that fosters plurality of opinions.

When we look to the fields that form a sustainable university, according to Arroyo (2017), the analysis of TV UFPB and the magazine reveals a situation of imbalance. The disclosure was the most explored aspect, even 
though interdisciplinarity does not seem to be a priority. Operations represent the third force since it was possible to observe sustainable practices, even if isolated. The speech ignored the debate to integrate sustainability into the curricula of the various courses taught at the university.

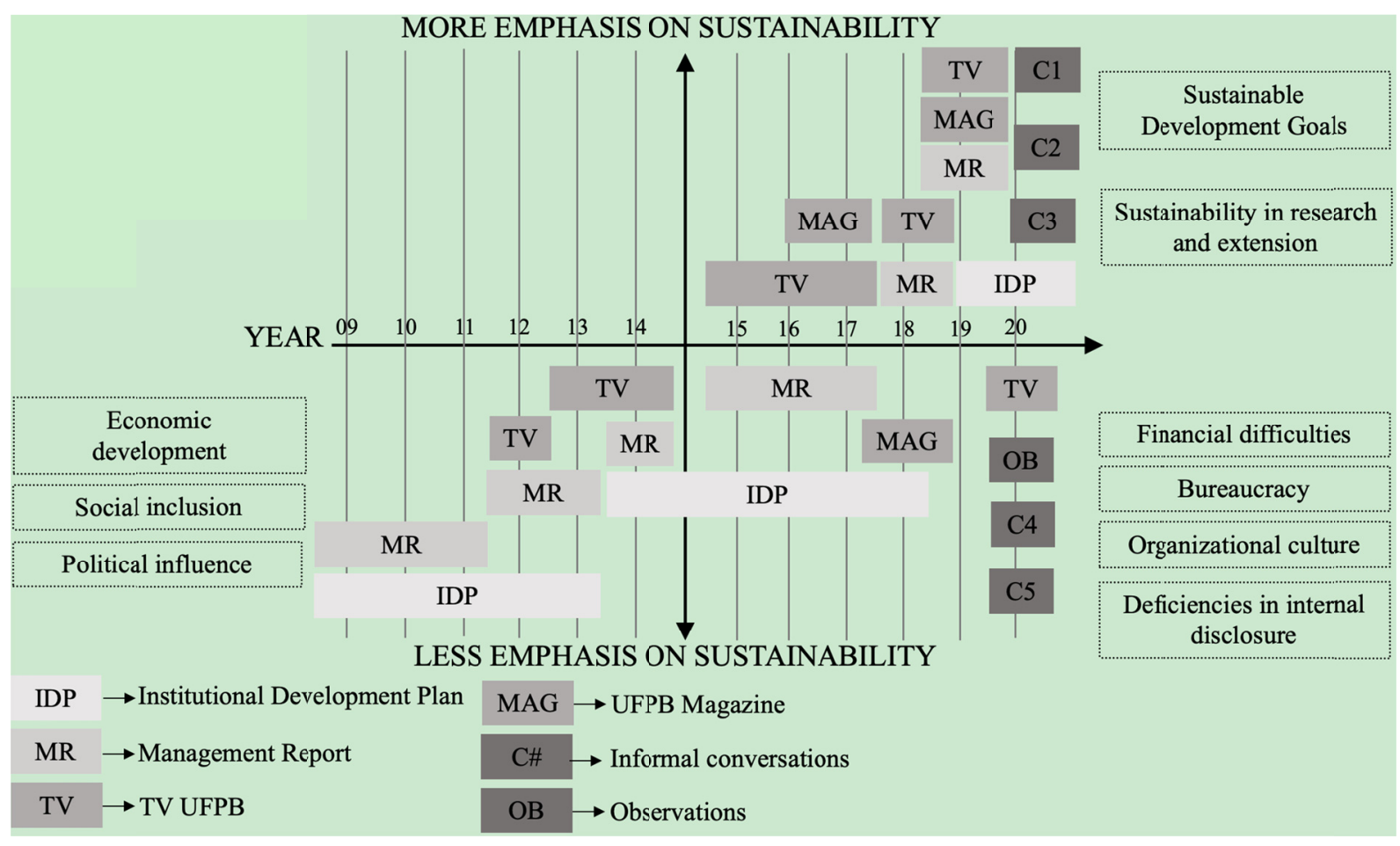

Figure 2. Positions of the sustainability discourse

Source: elaborated by the authors, 2021.

From the positioning map presented in Figure 2, we made some inferences about the evolution of the themes that permeate the Federal University of Paraiba's sustainability discourse over time. It is possible to notice, in Figure 3 , that the institution has moved from a fundamentally social understanding to the gradual assimilation of the relevance that environmental issues may have, while at the same time seeking to improve the means of unifying both factors in teaching, research, and extension.

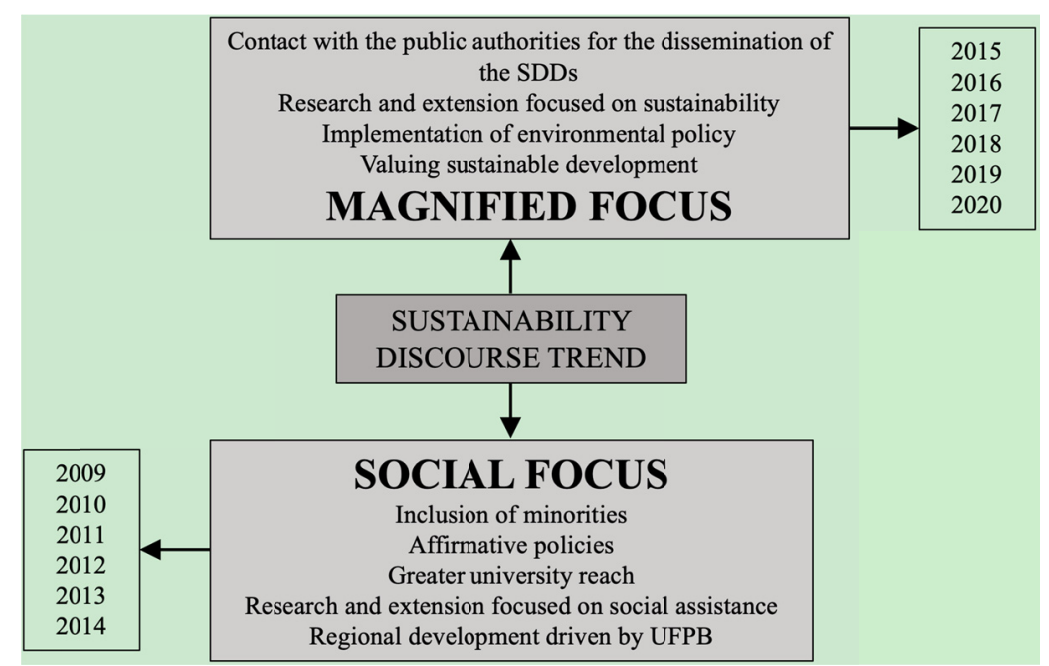

Figure 3. Trend of the evolution of the UFPB sustainability discourse 
The evolution of the perceived focus demonstrates that the university has opened its horizons to understand the scope of sustainability and its importance for fostering social and economic development. The organization has softened its discourse but did not abandon the idea of spread knowledge and accelerate the regional economy. At first, there was a latent desire to assume a socioeconomic role reserved for governments and private organizations. Gradually, the speech eased to present a company that seeks to assist these entities through knowledge, the formation of qualified individuals, and projects capable of developing economically viable and socio-environmentally clean and renewable technologies.

Informal speeches expose a contrast between this gradual greater institutional understanding and its internal application. For these discursive sources, UFPB directed the focus abroad-it is evident from the speeches expressed that they feel the need for an organism with autonomy and resources capable of establishing parameters, norms, and goals that drive a necessary transformation in the organizational culture.

From the conversations, it was possible to conclude that higher positions in the internal hierarchy tend to induce a politically correct discursive position, with a tendency to justify acts understood as adverse. Jobs that are not related to sustainability and in a lower hierarchical seat seem to give employees more freedom to criticize management. Figure 4 identifies the discursive positions of each of the participating workers.

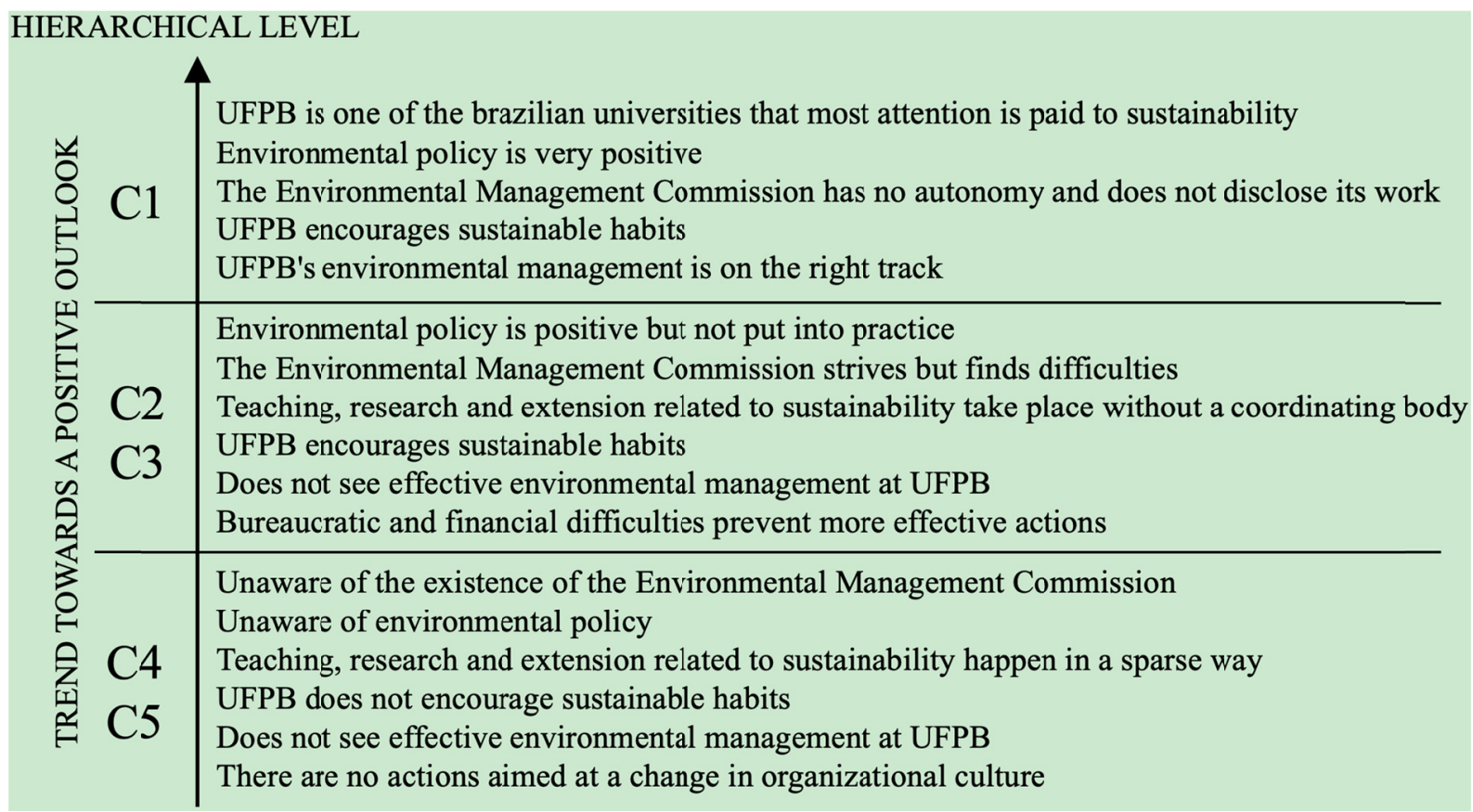

Figure 4. Employees' discursive positions

Source: elaborated by the authors, 2021.

Commonly, the workers consider that internal communication about sustainability is insufficient. It is particularly noticeable in $\mathrm{C} 4$ and $\mathrm{C} 5$ - both did not know about the existence of the Environmental Management Commission and UFPB's environmental policy. C2 stated that "there have already been some attempts at intersectoral work with the Environmental Management Commission, but I have not seen ... this interaction ... I believe that there is no scope in this communication as the university needs, understand?".

Employees in lower hierarchical positions were unaware of the decisions taken at higher levels, which impairs the effectiveness of these decisions. For $\mathrm{C} 5$, "there is a lack of communication... I think that this sector (the EMC) should have an open dialogue with employees, who are ... the heart of the university... and that we could propagate, understand?".

Different sectors do not communicate, do not exchange information, and do not plan joint actions for sustainability. "The first thing to do is to have better and greater communication between all sectors and agents that make up UFPB: managers, teachers, students, and administrative technicians need to act in concert so that we have a more sustainable university", said C3. 
We considered some words in the definition of institutional conduct, according to the discourse of workers: goodwill, isolated, propagation, prototypes, pilot-project. The arguments, in general, impelled the understanding that the institution seeks to improve its sustainability indexes, despite the lack of systemic work aimed at the valorization of the theme by the academic community to make it an integral part of everyday life. Bureaucratic difficulties, often resulting from ignorance and a lack of long-term vision, are points that slow down decision-making on issues that could potentially help the organization in the face of environmental, social, and financial challenges.

The images captured during the observations seem to support the opinions expressed in the conversations as they testify to several moments when the organization left the care for sustainability in the background. Deficiencies in waste collection, use of rainwater, water waste, design of buildings or their renovations, incorrect collection and disposal of useless material are factors that point to a fragile institutional capacity to enforce its environmental policy, in contrast to the discourse propagated by its official media.

\subsection{Narrative Configurations and Semantic Spaces}

The narrative configurations represent, to Coelho (2012), a way to bring latent content to the surface at the manifest level of texts and images, which provides a progressive chain of themes that configure the basis of Sociological Discourse Analysis. The official discourse traverse from the axis that understands, on the one hand, the virgin (untouched) nature and, on the other, the nature transformed by a sustainable economy. There is a propagation wave that represents the institution's social interests. They remained intertwined in the sustainability discourse manifested by different discursive sources over the years, as shown in Figure 5.

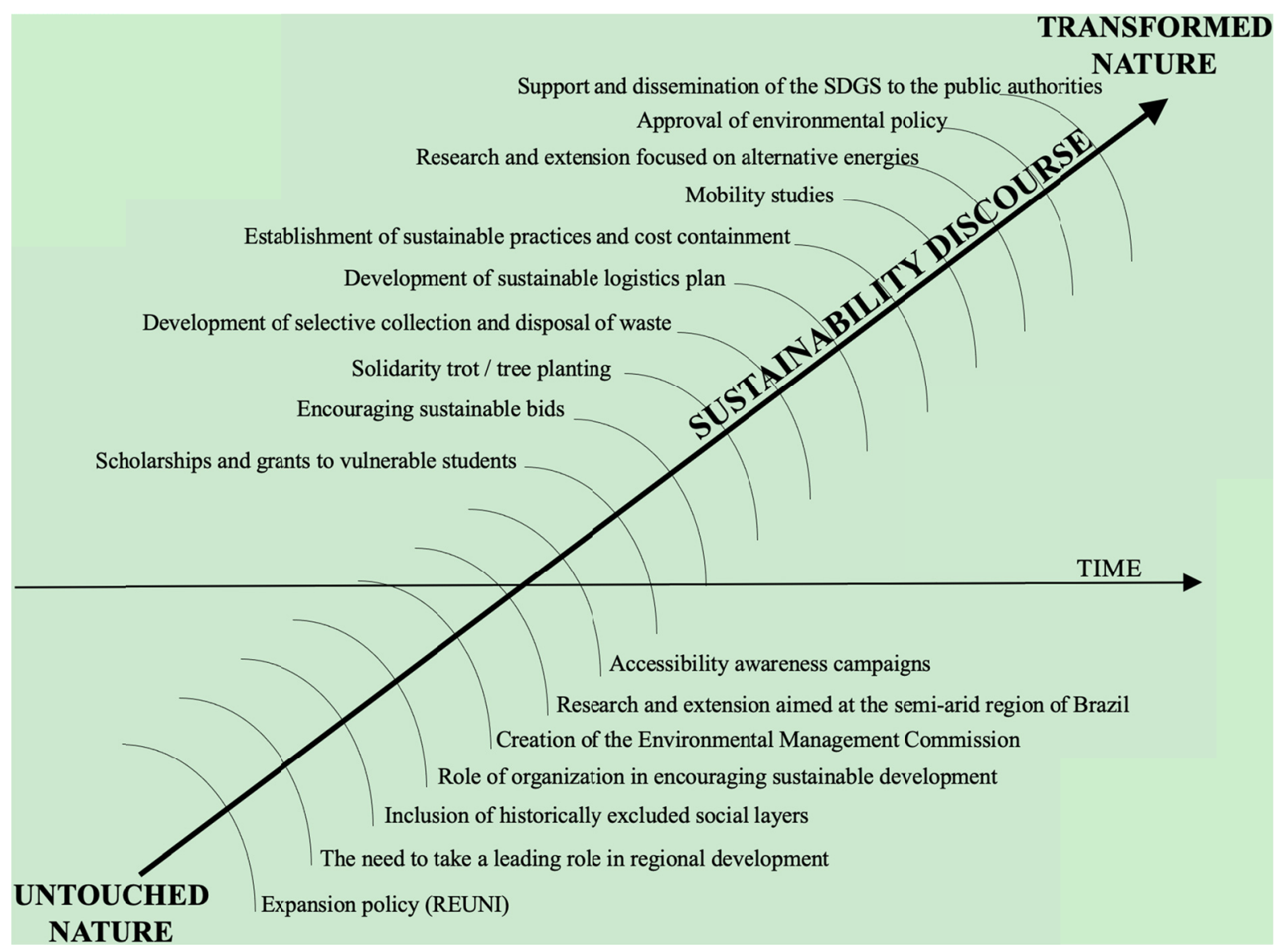

Figure 5. Narrative configuration of formal discourse manifestations

Source: elaborated by the authors, 2021. 
Considering the Triple Bottom Line, we observed that gradually the natural dimension gains space and blends with the social aspect, which previously dictated institutional paths. Progressively, both start to share synergies to better contribute to sustainable socio-economic development. The prioritization of society remains present, to the detriment of an internal look that could design ways to change the organizational culture and insert sustainable habits that modernize management, with consequent financial and image gains as advocated by North (1992), Paula, Waltrick, and Pedroso (2017), Ferrer et al. (2019) and other researchers.

Sustainable Development Objective number four, aimed at a quality education, is a constant throughout the discourse analyzed - as this is the primary reason for the UFPB existence, stakeholders expect that time and efforts are devoted to its improvement. What seems incomprehensible is that the organization did not give space to the exposure of methods and policies that lead to the inclusion of sustainability in the curriculum of courses. The university lost much learning by not promoting a global topic like this.

Considering interrelationships between the Sustainable Development Goals and the Triple Bottom Line, we understand that the university prioritizes the social dimension. It is apparent in the discourse how much the mission of generating benefits to society is decisive in the organizational culture. We found, throughout the analysis, that the institution attempted to remain active amid periods of financial difficulties and at times when government policy highly valued public education. In both moments, UFPB paid attention to the needs of the labor market and the concerns of social minorities, with an organization that tried to act within its means to keep itself updated and socio-economically relevant. In this scenario, both education for sustainability and incentive to sustainable acting happened without reaching the priority level in pedagogical and management policies.

The exam of the informal discourses leads to the understanding that they tend to separate into two antagonistic blocks. At one extreme, they relate to politically correct ideas that the university is proactive in its relationship with sustainability. Nevertheless, the university only reacts to the gradual increase of social and academic importance concerning sustainability, with few relevant attitudes developed internally to change reality perceived through discursive sources. Figure 6 illustrates this dichotomy.

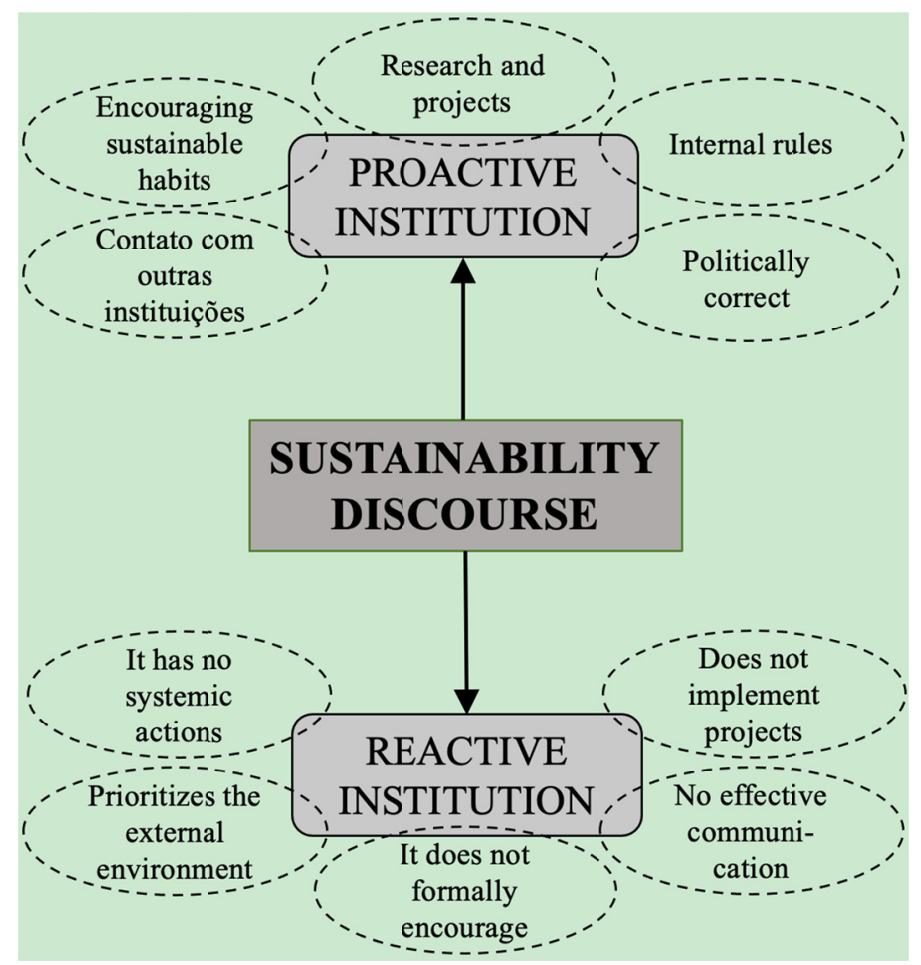

Figure 6. Narrative configuration of informal discourse manifestations

Source: elaborated by the authors, 2021.

Employees who occupy higher positions prefer the politically correct discourse within the hierarchy of power. However, there is an understanding that the organization directs attention to policies for vulnerable students, research and extension projects in regions recognized as pockets of socioeconomic vulnerability, or even making 
contact with public and private organizations to expand their knowledge about socio-environmental responsibility. Only the hierarchically inferior group realizes that there is a weakness in the internal management of sustainability.

Figure 7 shows the semantic spaces of the manifested discourse, defined from the discursive sources, given the relevant areas for the formatting of a sustainable university, according to Arroyo (2017). These spaces are related to the set of lexical units with an underlying structural organization. All the four areas that contribute to a sustainable university emerge in the graphic: they interact, enhance, or challenge the progress of the others. The positive semantic spaces stand out in gray.

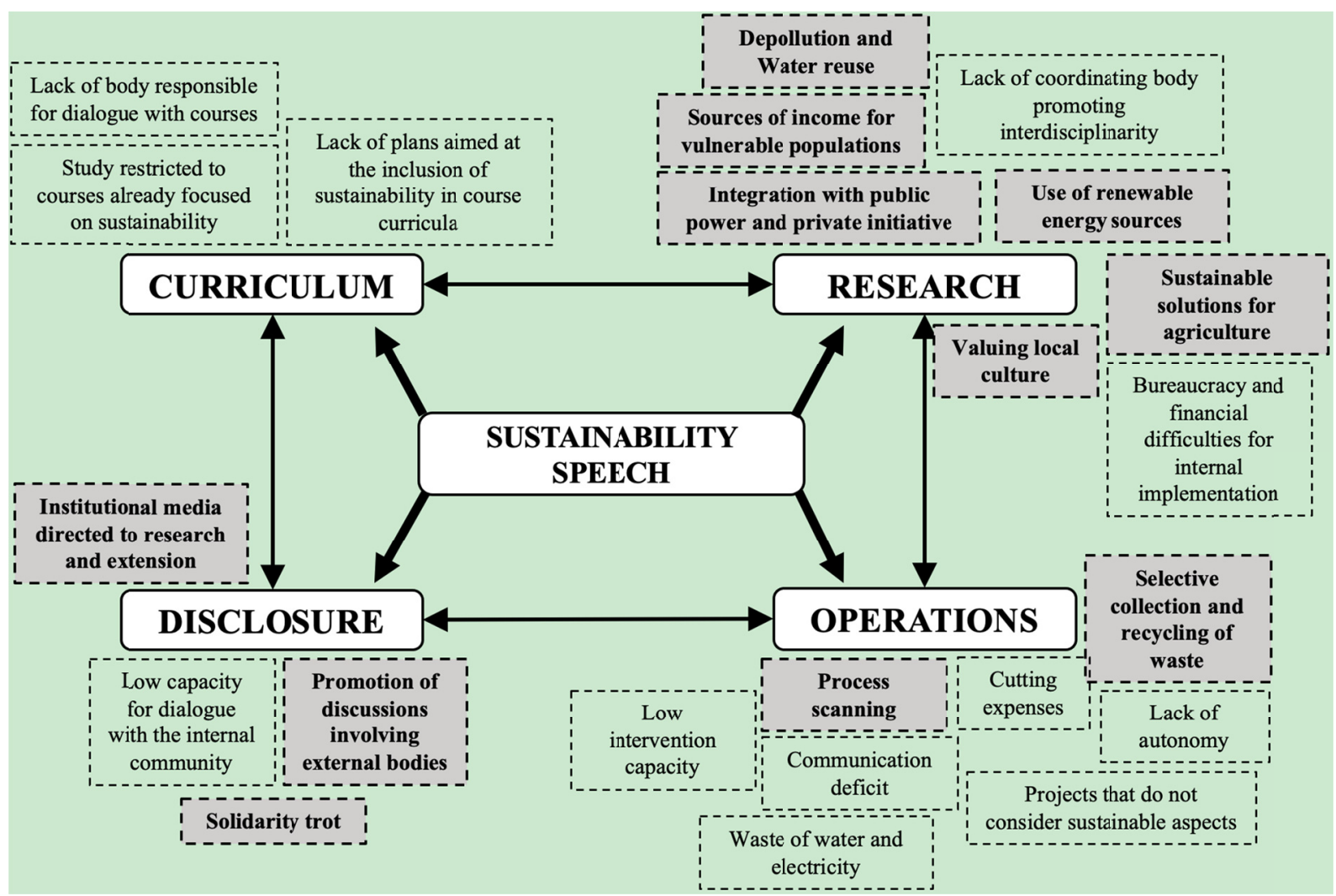

Figure 7. Semantic spaces of discursive sources concerning the relevant areas for a sustainable university, according to Arroyo (2017)

Source: elaborated by the authors, 2021.

The sustainability discourse expressed by the Federal University of Paraiba emphasizes its social role. The organization intends to rescue historically excluded populations through student aid policies and actions that can contribute to socio-economic advancement in regions lacking natural resources and public services, such as the case of the northeastern semi-arid. Isolated university centers present projects aimed at society and experience difficulties related to the internal application of sustainable actions. The lack of an entity with autonomy and breadth to manage behavior, promoting internal dialogue and interdisciplinarity, harms not only this implementation but contributes to the excess of bureaucracy and the inadequate or wrong targeting of financial resources.

The decisive factors for the implantation of a culture focused on sustainability in universities, according to Adams (2013), resulted in Table 3, which expresses UFPB's position concerning each factor and suggestions of alternative attitudes that could contribute to an improvement in the indicated situation. 
Table 3. UFPB positions about sustainability and alternatives for improvement

\begin{tabular}{|c|c|c|}
\hline FACTOR & SPEECH VERSUS REALITY & IMPROVEMENT ALTERNATIVES \\
\hline Proactive Leadership & $\begin{array}{l}\text { Reactive leadership or with little } \\
\text { autonomy }\end{array}$ & $\begin{array}{l}\text { More autonomy for sectors that work with sustainability and mandatory } \\
\text { participation in strategic and operational decision-making; search for } \\
\text { certifications; establishment of goals for reducing the consumption of } \\
\text { resources }\end{array}$ \\
\hline $\begin{array}{l}\text { Clear and consistent } \\
\text { communication }\end{array}$ & $\begin{array}{l}\text { Deficiencies in transmission of } \\
\text { information }\end{array}$ & $\begin{array}{l}\text { Investment in internal communication and the demand for greater } \\
\text { transparency in communication between managers and subordinates; } \\
\text { promoting a healthy environment }\end{array}$ \\
\hline $\begin{array}{l}\text { Inclusion of sustainability } \\
\text { in organizational strategy }\end{array}$ & $\begin{array}{l}\text { Secondary role of sustainability in } \\
\text { strategy }\end{array}$ & $\begin{array}{l}\text { Preparation of checklists on sustainability, mandatory for decision making; } \\
\text { evaluation of different sources of financial resources }\end{array}$ \\
\hline $\begin{array}{l}\text { Multidisciplinary in } \\
\text { courses and research }\end{array}$ & $\begin{array}{l}\text { Isolated actions, deficient } \\
\text { communication between sectors }\end{array}$ & $\begin{array}{l}\text { Joint work between sectors with the definition of goals related to } \\
\text { sustainability; agreements between university, government, and private } \\
\text { initiative for the development of collective research and extension works }\end{array}$ \\
\hline $\begin{array}{l}\text { Engagement of students } \\
\text { and employees }\end{array}$ & $\begin{array}{l}\text { Low engagement, ignorance of } \\
\text { existent actions }\end{array}$ & $\begin{array}{l}\text { Clear and transparent communication, the definition of goals and awards for } \\
\text { courses and administrative bodies; scholarships in the area of sustainability; } \\
\text { use of the university's physical space as a testing area for conducting } \\
\text { research }\end{array}$ \\
\hline $\begin{array}{l}\text { Other initiatives that can } \\
\text { develop sustainable } \\
\text { practices }\end{array}$ & $\begin{array}{l}\text { Bureaucracy and financial } \\
\text { difficulties }\end{array}$ & $\begin{array}{l}\text { Implementation of a body with autonomy and resources for the coordination } \\
\text { and implementation of actions, projects, and research related to } \\
\text { sustainability; negotiation with water and energy companies to implement } \\
\text { policies for generation, reuse, and reduction in consumption }\end{array}$ \\
\hline
\end{tabular}

Source: elaborated by the authors, 2021.

Any discourse manifestation carries interests and cannot be considered naive (Coelho, 2012). In this sense, a public organization, funded and maintained with government resources, tends to carry its discourses with the responsibility of giving back to society the money invested there. It may happen with quality education and actions that could accelerate socio-economic development. The Federal University of Paraiba respects laws related to sustainable habits. It also demonstrates interest in being an avant-garde organization in its relationship with socio-environmental responsibility and the spread of knowledge and technologies that contribute to sustainable development. However, the presence of contradictions in the manifested speech reveals a delay in applying the existing environmental policy and difficulties in the management of communication focused on the theme. Its recognition as a sustainable university acquires a myth bias in the academic community, demonstrating the need for adequate, transparent, and well-publicized actions that can, over time, change this view.

\section{Final Remarks}

This research started with concerns that asked about the management focused on sustainability in federal institutions of higher education and how these entities would manifest their discourse related to the theme. As a procedure for the study of data collected during the investigation, we used Sociological Discourse Analysis, a qualitative research method based on practices derived from sociology, to understand discursive manifestations.

Based on the results presented, it is evident that the discourse of sustainability expressed by the Federal University of Paraiba prioritizes the social field in what concerns research, extension projects, and joint policies with public and private companies. These priorities could help regions that experience environmental problems (the northeastern semi-arid, riverside areas that suffer from pollution, or areas that need to preserve biomes and animal species) and socioeconomic difficulties arising from a history of exclusion and few opportunities for professional development. The institution seeks to spread knowledge about sustainable plans such as the Sustainable Development Goals by promoting events aimed at public managers, despite the lack of robust planning linked to their implementation in the structure itself.

We based this study on some questions. They clarified the capture of speeches and silences while allowed the observation of the reality constructed by the organization:

a. Who speaks? The Federal University of Paraiba, an organization responsible for the discourse elaboration. It prioritizes one of the dimensions of sustainability expressed in the Triple Bottom Line, the social, which is beyond the understanding of researchers such as Arroyo (2017) and Adams (2013), for whom systemic and holistic thinking must prevail in sustainable universities.

b. What is the position of the speaker? A public, non-profit organization with planning to reduce social inequalities and promote social welfare and economic development with its services: teaching, research, and extension. The largest and oldest university in its state, the university aims to be a propagator of 
knowledge and an accelerator of regional development, prioritizing socioeconomic sustainability.

c. What are the subjects addressed in the speeches? Organizational planning to achieve its objectives, linked to quality education and involvement with society to reduce social inequalities and encourage regional economic development. It is evident in the speech that the university aims to be the developer center for technologies and policies that preserve regional culture and ecosystems, which contradicts the low implementation of sustainable actions at home.

d. What is not said but perceived in the speeches? The easing of regional socioeconomic inequalities and the inclusion, in the economic process, of historically excluded layers of society. The links between economy and new technologies, professions, and working methods to raise environmental, social, political, and economic issues around long-term sustainable development. The continuity and expansion of the works developed suffer setbacks due to contexts of financial difficulties, which expresses the institution's lack of clarity regarding benefits in this sense that could result from sustainable practices.

e. How is the discourse organized? The speech seeks to manifest the understanding of the organization's socio-environmental responsibility and its role as a sponsor of transparency and dialogue between different organizations. Over the years, the eminently social discourse has given space to environmental aspects, remaining politically correct and with lenses turned to the outside world. The silence about presumed benefits from sustainable actions carried out at the domestic level gives low attention to the relevance of sustainable universities, a theme studied by several entities at the international level.

One limitation of this study is the evidence that we captured the analyzed images from our perspective, actively inserted on the observed reality. This circumstance makes it challenging to keep the distance expected when carrying out a study of this size. The option for stock images can give future researchers a broader view of the object of study since their perspective - which carries their ideologies - would not influence the abstractions. Despite considering this a limitation, the personal capture of images, even if it brings the researcher's own bias, does not invalidate the research or the interpretation of the facts since the university is a space open to visitation, allowing ample research possibilities to interested parties.

The temporary lockdown due to the COVID-19 pandemic in 2020 made it impossible to make in-depth observations on all the UFPB's campuses. We prioritized campus I, the largest of them, located in Paraiba's capital. This fact may have compromised to some degree the perception of actions taken or omissions by the university administration. For the same reason, we conducted conversations with employees electronically. This eliminated part of the spontaneity of responses on certain occasions - we believe that communication conducted in person can stimulate a feeling of intimacy between the interlocutors, with a consequent more detailed and in-depth reply. However, the material collected proved to be adequate for the analysis.

We suggest to future researchers who wish to work with the discourse of sustainability in organizations, particularly in universities, to work with discussion groups and surveys in addition to the search for the realization of conversations in person, avoiding, as far as possible, the use of electronic means for this.

We recommend continuing the analysis of the Institutional Development Plans and Management Reports, as these documents present in a striking way the history of the period to be studied. In the same way, the media productions of the organization itself are material rich in signs of the ideologies that determine the institutional direction. We suggest a resumption of the Federal University of Paraiba's discourse analysis itself so that comparisons can be made with the findings of this research, thus obtaining a broader view on the evolution of the sustainability discourse manifested by this institution over time.

We hope that this study will serve as a stimulus for reflection on the role of organizations in promoting sustainable development. We understand that university management that is more aware of the relevance of sustainable thinking can contribute decisively to the process of free experimentation, reflection, and promotion of ethical, critical education and committed to living in community, with the conservation of natural resources and with social justice.

\section{References}

Adams, C. A. (2013). Sustainability reporting and performance management in universities. Sustainability Accounting, Management and Policy Journal, 4(1), 384-392. https://doi.org/10.1108/SAMPJ-12-2012-0044

Aleixo, A. M., Leal, S., \& Azeiteiro, U. M. (2018). Conceptualization of sustainable higher education institutions, roles, barriers, and challenges for sustainability: an exploratory study in Portugal. Journal of Cleaner Production, 172(1), 1664-1673. https://doi.org/10.1016/j.jclepro.2016.11.010 
Aligleri, L., Aligleri, L. A., \& Kruglianskas, I. (2009). Gestão socioambiental: responsabilidade e sustentabilidade do negócio. São Paulo: Atlas.

Alonso, L. E. (1998). La mirada cualitativa en sociologia. Madrid: Fundamentos.

Alonso, L. E., Rodriguez, C. J. F., \& Rojo, R. I. (2016). De la moral del sacrificio a la conciencia de la precariedad: un análisis cualitativo de los discursos sobre la evolución de la crisis en España. Política y Sociedad, 53(2), 353-379. https://doi.org/10.5209/rev_POSO.2016.v53.n2.49380

Arroyo, P. (2017). A new taxonomy for examining the multi-role of campus sustainability assessments in organizational change. Journal of Cleaner Production, 140(1), 1763-1774. https://doi.org/10.1016/j.jclepro.2015.08.100

Barros, T. H. B. (2015). Uma trajetória arquivistica a partir da análise do discurso. São Paulo: UNESP. https://doi.org/10.7476/9788579836619

Bastos, A. M. (2016). Dossiê DEDS (2005 a 2014) - a década da educação para o desenvolvimento sustentável no Brasil: uma análise pela perspectiva estratégica. Doctoral dissertation. Universidade Estadual Paulista, Araraquara, Brazil. Retrieved from http://hdl.handle.net/11449/144999

Carvalho, G. O. (2019). Sustentabilidade e desenvolvimento sustentável: uma visão contemporânea. Revista Gestão \& Sustentabilidade Ambiental, 8(1), 779-792. https://doi.org/10.19177/rgsa.v8e12019789-792

Carvalho, P. G. M., \& Barcellos, F. C. (2015). Os objetivos de desenvolvimento do milênio: uma avaliação crítica. Rio de Janeiro: IBGE.

Coelho, A. L. A. L. (2012). Construção do discurso da sustentabilidade: uma prática de análise sociológica do discurso no campo organizacional. Doctoral dissertation. Universidade do Vale do Itajaí, Biguaçu, Brazil. Retrieved from https://siaiap39.univali.br/repositorio/handle/repositorio/2182

Coelho, A. L. A. L., Coelho, C., \& Godoi, C. K. (2013). O Discurso da sustentabilidade e sua inserção no contexto organizacional. Revista Gestão \& Conexões, 2(1), 147-186. https://doi.org/10.13071/regec.2317-5087.2013.2.1.5061.147-186.

Conde, F. (2009). Análisis sociológico del sistema de discursos. Madrid: Centro de Investigaciones Sociológicas.

Ferrer, F. C. S., Moreira, J. R., \& Jesus, J. S. (2019). A responsabilidade social das empresas: uma análise além do discurso organizacional. Revista Negócios em Projeção, 10(1), 205-219. https://doi.org/10.19177/rgsa.v8e12019789-792

Godoi, C. K., Coelho, A. L. A. L., \& Serrano, A. (2014). Elementos epistemológicos e metodológicos da análise sociológica do discurso: abrindo possibilidades para os estudos organizacionais. Revista O\&S, 21(70), 509-536. https://doi.org/10.1590/S1984-92302014000300009

Godoi, C. K., \& Uchoa, A. G. F. (2019). Metodologia de análise sociológica discursivo-imagética: possibilidades aos estudos organizacionais. Organizações \& Sociedade, 26(91), 776-794. https://doi.org/10.1590/1984-9260918

Hammer, J., \& Pivo, G. (2016). The triple bottom line and sustainable economic development theory and practice. Economic Development Quarterly, 31(1), 25-36. https://doi.org/10.1177/0891242416674808

Ibanez, J. (1985). Del algoritmo al sujeito: perspectivas de la investigación social. Madrid: Siglo XXI.

Laurell, H., Karlsonn, N., Lindgren, J., Andersson, S., \& Svensson, G. (2019). Re-testing and validating a triple bottom line dominant logic for business sustainability. Management of Environmental Quality, 30(3), 518-537. https://doi.org/10.1108/MEQ-02-2018-0024

Nascimento, E. P. (2012). Trajetória da sustentabilidade: do ambiental ao social, do social ao econômico. Estudos Avançados, 24(74), 51-64. https://doi.org/10.1590/S0103-40142012000100005

North, K. (1992). Environmental business management. Geneva: International Labor Office.

Orlandi, E. P. (2015). Análise de discurso: principios \& procedimentos (12th ed.). Campinas: Pontes Editores.

Orti, A. (1986). La apertura y el enfoque cualitativo o estructural: la entrevista abierta semidirectiva y la discusión de grupo. In M. Garcia, J. Ibanez \& F. Alvira (Eds.), El análisis de la realidad social: métodos y técnicas de investigación (pp. 153-185). Madrid: Alianza.

Pantaleao, C. C. (2017). Campus universitário como laboratório vivo para sustentabilidade: proposição de critérios analíticos. Master's thesis. Universidade Nove de Julho, São Paulo, Brazil. Retrieved from 
http://bibliotecatede.uninove.br/handle/tede/1757

Paula, A. C. P., Waltrick, M. S., \& Pedroso, S. M. (2017). Sustentabilidade organizacional: desafio dos gestores frente às questões ambientais. In J. H. P. Silveira (Ed.), Sustentabilidade e responsabilidade social: artigos brasileiros (vol. 3, pp. 6-15). Belo Horizonte: Poisson.

Paula, C. H. (2018). An influência do REUNI sobre o desempenho das instituições federais de ensino superior. Master's thesis. Universidade Federal de Viçosa, Viçosa, Brazil. Retrieved from https://locus.custom.ufv.br//handle/123456789/20941

Roma, J. C. (2019). Os objetivos de desenvolvimento do milênio e sua transição para os objetivos de $\begin{array}{llllll}\text { desenvolvimento } \quad \text { sustentável. } & \text { Ciência } & e & \text { Cultura, } & 71(1),\end{array}$ https://doi.org/10.21800/2317-66602019000100011

UFPB. (2010). Plano de Desenvolvimento Institucional 2009-2012. Universidade Federal da Paraíba. Retrivied February 01, 2020 from http://www.ufpb.br/cpa/contents/arquivos/pdi-ufpb-2009-2012.pdf/view

UFPB. (2014). Plano de desenvolvimento institucional 2014-2018. Universidade Federal da Paraíba. Retrivied February 02, 2020 from http://www.de.ufpb.br/graduacao/res/PDI20142018.pdf

UFPB. (2018). Resolução 17/2018. Retrivied February 25, 2020, from https://www.ufpb.br/prac/contents/paginas/portaarquivos/ResoluoCONSUNI17_2018.pdf

UFPB. (2019a). Plano de Desenvolvimento Institucional 2019-2023. Universidade Federal da Paraíba. Retrivied March 01, 2020, from http://www.proplan.ufpb.br/proplan/contents/documentos/pdi/pdi_2019-2023_posconsuni-1.pdf

UFPB. (2019b). Relatórios de gestão. Universidade Federal da Paraíba. Retrivied 12 de dezembro de 2019, from http://www.proplan.ufpb.br/proplan/contents/menu/ploplan/relatorio-de-gestao

UFPB. (2019c). UFPB em números: 2012-2018. Universidade Federal da Paraíba. Retrivied December 15, 2019, from https://www.ufpb.br/ufpb/contents/documentos/outros-pdfs/ufpb-numeros_2012-2018.pdf

UNESCO. (2017). 2005-2014: década das Nações Unidas de educação para o desenvolvimento sustentável. Organização das Nações Unidas para a Educação, a Ciência e a Cultura. Retrivied October 10, 2019, from $\mathrm{http} / / / \mathrm{www}$.unesco.org/new/pt/brasilia/about-this-office/prizes-and-celebrations/2005-2014-the-united-natio ns-decade-of-education-for-sustainable-development/

\section{Copyrights}

Copyright for this article is retained by the author, with first publication rights granted to the journal.

This is an open-access article distributed under the terms and conditions of the Creative Commons Attribution license (http://creativecommons.org/licenses/by/4.0/). 